\title{
International Economic Co-operation in the Carpathian Region
}

\author{
László Dankó \\ Department of Applied Economics, University of Miskolc, Miskolc, \\ Hungary
}

\section{Introduction}

This article looks into the past and future of the potential of economic cooperation in the region named after the Carpathian mountains. This region is made up of parts of five countries - the Czech and Slovakian Federal Republic, Poland, Hungary, Rumania and Ukraine - in Middle-Eastern Europe that will be defined later. This paper will establish how regional economic co-operation may be mutually beneficial after the East-European military and political block in 1990-91 was dismantled. In order to avoid misunderstanding it must be stressed that the regional co-operation is not thought to be an alternative to the European integration, but a step towards becoming a European country, in which it can prepare for a more extensive economic integration.

However, it must also be emphasised that, because of the depressed economic situation and unsettled market conditions of these subregions, the countries can give less economic impulse to each other than might be given by developed countries in a new "Marshal Plan". This paper presents arguments about the potential and the initial results of co-operation. It draws attention of those potential investors who wish to establish businesses with direct capital investment, to the region's natural and economic advantages.

The Carpathian region is a historical and geographical continuation of the "Euroregion Baseliensis", which was established by French-German cooperation, the Alps-Adriatic Partnership and the Adriatic-Danube (Pentagonal) Partnership. It is believed that because of the excessive industrialisation, environmental pollution and urbanisation Europe's former economic centres (the developed British and Middle-European regions) will move to the above-mentioned natural region, where - mainly through small and middle sized business - the establishment of a new European economic centre of power will be established. Hungary as a member of Alps-Adriatic and Adriatic-Danube regional co-operation can act as a bridge between East and West with the extension of the idea of regional co-operation towards the East.

It is believed that successful international co-operation may develop out of such regional co-operation with a mosaic-like build-up akin to the European Community's expansion and association policies. 
International

Business

Review

2,3
Overview of the Economic History of the Region

Integration liberal theory is based on the theories of classical civil economics, on the assumptions of the traditional freetrade doctrine and on the promotion of perfect competition. According to this theory, integration is possible where the free movement of goods, services and methods of production are realised. "I define the economic integration as the levelling-off of the cost of production factors, in other words the levelling-off of salaries, interest and profit" (Kindleberger, 1966).

The example of the preferential customs zone within different forms of integration shows clearly that countries in such areas provide customs and trade advantages to each other (e.g. the British preferential customs system, created in 1932, Surányi, 1990).

As an economic unit the Hapsburg Empire had such a preferential customs system. Under the rule of Károly (Charles) VI (1711-1740) — the third as a Hungarian king - this system's development started in the Hapsburg Monarchy, in the spirit of consistent mercantile policy. Up to that time each kingdom and province was an independent economic entity, but he introduced "transit", i.e. he made it possible for the goods produced in one Hapsburg country to be transported to other countries duty-free. Later rulers also followed this policy, and in 1775 the Czech and Austrian provinces (except Tyrol) became part of an integral customs union. Slowly, all the countries of the empire became part of a unified market. Division of labour was developing between the provinces: wool and glass were produced in

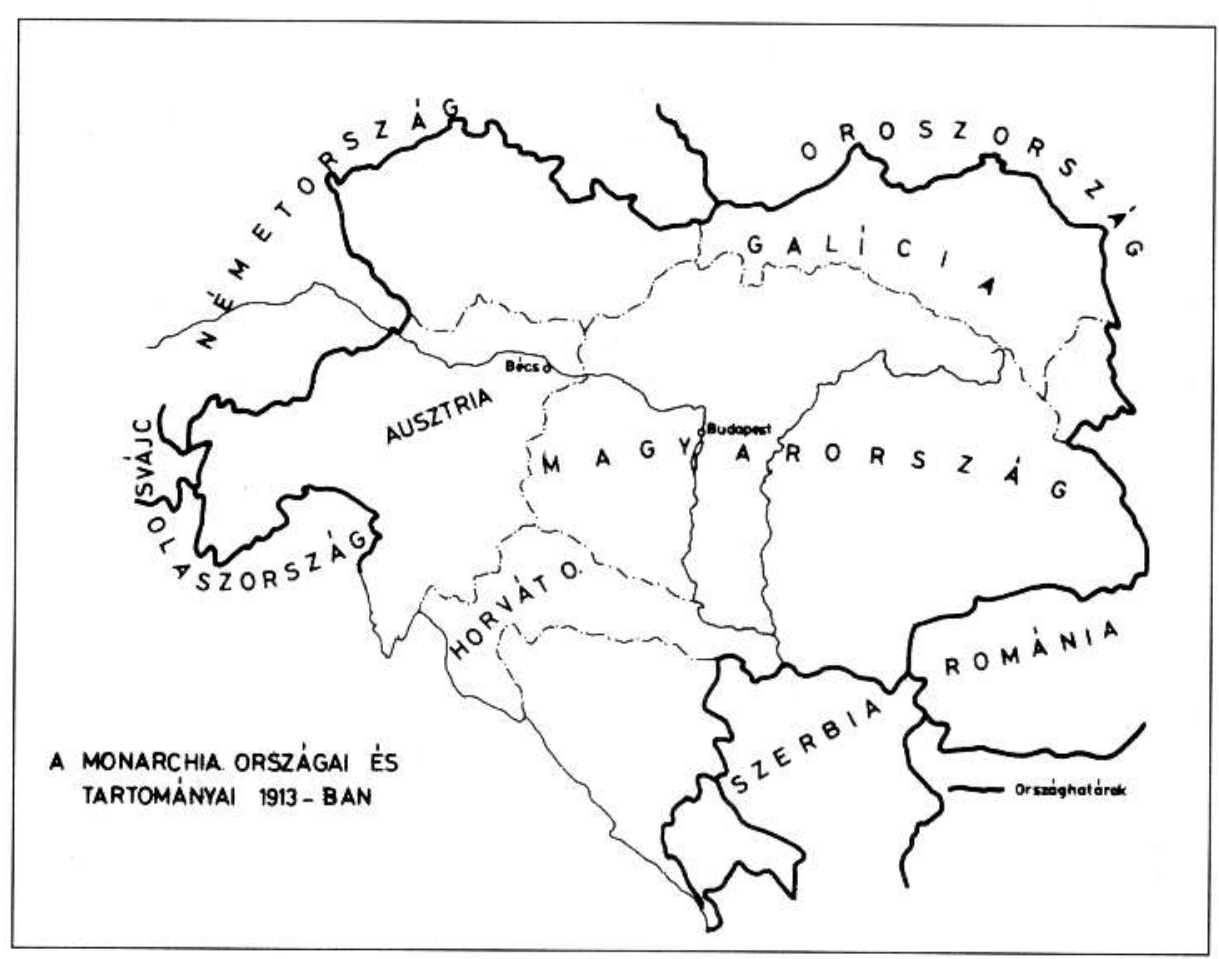

\section{Figure 1.}

The Austro-

Hungarian Empire and its Neighbours in 1913 
Bohemia, textiles in Moravia, iron in Upper-Austria and luxury goods in Vienna for the whole Monarchy (Fig. 1).

Only Hungary remained strictly economically delimited until the middle of the 19 th century. This situation was not brought about by the Hungarian chauvinism, but by the nobility's narrow-minded policies. By insisting on their ancestral feudal privileges they refused to pay taxes, and so it was only possible to get financial contributions from them through customs on Hungarian wheat, cattle and other goods.

The main demand of the Hungarian liberal opposition in the two decades preceding the revolution of 1848 was customs union, but just before the revolution total economic independence became the main objective. This effort was the main reason that, after the defeat of the revolution in 1850 , the Austro-Hungarian customs union was created as an instrument to exclude particularist tendencies (Jászi, 1982).

Freetrade in the Monarchy made it possible for the regions with different natural resources, culture and levels of economic development to develop mutually advantageous trade among themselves on the basis of comparative advantages. At the same time international competition was stopped at the borders of the market of 50 million customers by import duties (which were one-third of the value of the goods) and by strict import-controlling quotas to promote the development of industry and agriculture.

Thus economic integration was developing, and served as an incentive to the spread of impulses of growth from the developing western regions to the less-developed eastern regions. This process was so powerful that the development gap which had been growing until the middle of the 19th century, between the West and East, started narrowing. The lessening of difference was more the characteristic of certain less-developed regions than of others, but it could be felt throughout the Monarchy during the second half of the century.

In the Empire the infrastructure for trade was taking shape favourably. The development of modern transport systems was aided by concessions handed out for railway construction and by interest guarantees supported by the state (Table 1).
International

Economic

Co-operation

\begin{tabular}{|rr|}
\hline Year & $\begin{array}{c}\text { Length } \\
(\mathrm{km})\end{array}$ \\
\hline 1837 & 14 \\
1848 & 1249 \\
1867 & 6340 \\
1873 & 15597 \\
1880 & 18508 \\
1890 & 26519 \\
1900 & 36330 \\
1913 & 44748 \\
\hline
\end{tabular}

Table 1.

The Development of Railways in the Austro-Hungarian Monarchy (1837-1914) 


International
Business
Review
2,3

International

2,3
By 1913 the railway network in the Monarchy was in third place in Europe, after the Russian Empire and Germany. It was characteristic of the inflow of foreign working capital to Hungary that between 1867 and 1914, $40 \%$ of all investments (about 6800 million Crowns), were paid by Austrian and foreign capital. An example of the establishment of the Hungarian bank and loan system was the Pesti Hazai Elsö Takarékpénztár (First National Savings Bank of Pest), which was founded in 1836. Following this, by 1873, there were 637 financial institutions working in Hungary (Bereud and Ránki, 1987).

The transport and bank systems played a key role in the development of the modern economy and both of them are related to the boom in agriculture, which, although the Monarchy was developing in the name of economic selfsufficiency, played an important role in encouraging sectors of export too for example, in sugar, milling, brewing and distillation. Hungary's foreign trade turnover (outside the Monarchy) between 1882 and 1912 increased from 1763 million to 4174 million Crowns and the ratio of employees in trade and industry increased from 4.9 to $25.1 \%$ (Jászi, 1982).

The German middle classes were the leaders of capitalist economic development, and their power spread to the whole Monarchy from Vienna and from Czech industrial environment. German enterprises had representatives, branches and subsidiaries in every country and capital of the Empire.

The widespread markets of the Empire created economic possibilities, which were advantageous for every part of the Empire. Different regions chose not to develop every sector of their economy, but to invest their resources in the most advantageous ones. This phenomenon and the absence of foreign exchange problems inside the boundaries of the Empire greatly promoted economic development.

"There are only a few places in the world - perhaps the United States, Britain and its Commonwealth, - where economic co-operation between the regions has attained such a high level as the former Austro-Hungarian Monarchy. Strong cartels were formed in many sectors (in iron industry, in sugar industry) and the division of labour worked well on the basis of comparative advantages" (Hanák, 1991).

In 1919, after the peace talks near Paris, which brought about the conclusion of the First World War, the Austro-Hungarian customs union was broken up into seven parts (Fig. 2). The complementary areas of the country, which up to that time were helping each other; changed into self-sufficient, perhaps even hostile, states and each of these has lost part of its economic efficiency, so the end of the customs union was harmful for people living in this region.

Agriculture and some of the industrial sectors were left without a ready market, and were cut off from the resources of raw materials. For example, the Rimamurány Ironworks lost its iron-ore mines at Gömör, and at the same time the Vitkovic Ironworks lost its iron-ore resources at Rudabánya. Discrimination, political, and economic opposition have taken the place of the former regional economic co-operation inside the Monarchy. The statistical 


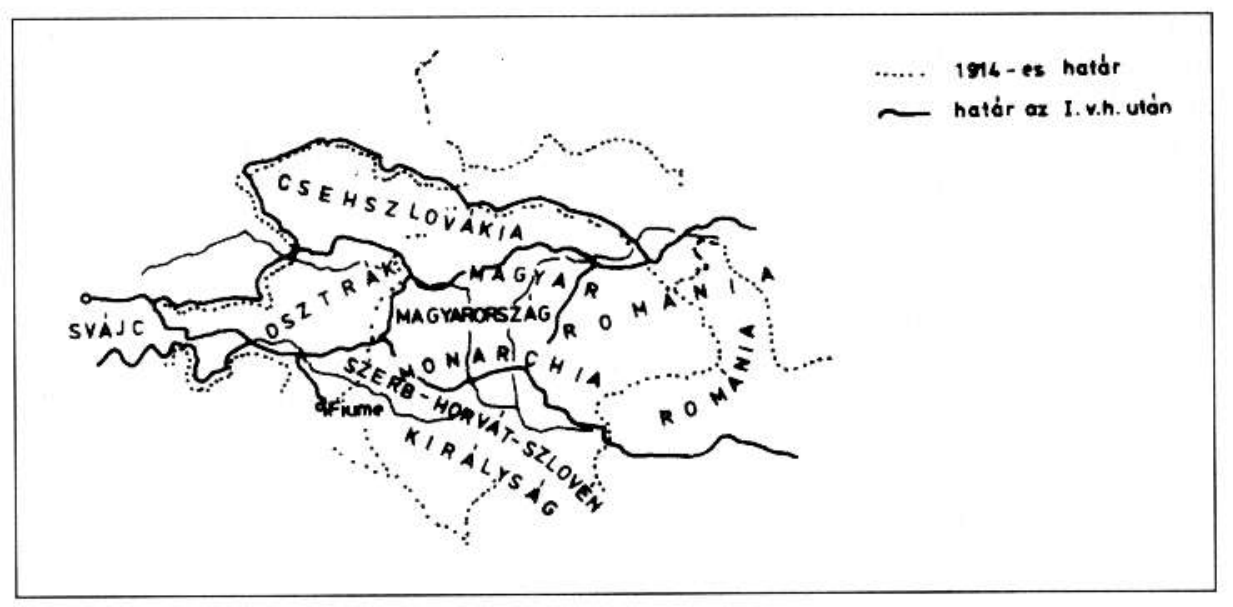

figures, however, show that tradesmen have found the way to realise their turnover mainly in the form of compensation transactions (Table 2, Hungarian Statistical Almanac, 1944).

Territorial settlements following the Vienna Decisions (reannexation of Upper Hungary, North Transylvania and the Vajdasag) have temporarily, though only partly, restored the economic co-operation among the neighbouring areas of the country. In the Carpathian region, for example, the iron and metal industries between Rima, Murány and Hernád rivers restored normal economic connection, and North-Hungarian agricultural products found customers among the food industries and population of the reannexed territories.

After the Second World War the region's structure of production, consumption and distribution, developed over centuries, disintegrated totally. In its place the COMECON's peculiar international economic organisation was formed, and the Soviet Union became the main trading partner for each of the small successor states. The Soviet type of centralised economic organisation, the introduction of state monopolies over foreign trade and foreign exchange and moreover, the effort to achieve absolute sovereignty

\begin{tabular}{|lrrrrrrrr|}
\hline Country/Year & 1922 & 1924 & 1929 & 1933 & 1935 & 1938 & 1940 & 1942 \\
\hline Austria & 32.4 & 27.8 & 21.7 & 23.9 & 19.1 & 14.9 & - & - \\
Czechoslovakia & 20.5 & 23.8 & 19.0 & 8.6 & 4.7 & 5.3 & 6.6 & 6.8 \\
Rumania & 8.8 & 6.0 & 6.8 & 5.2 & 9.2 & 6.9 & 3.0 & 0.8 \\
Yugoslavia & 5.1 & 5.7 & 5.5 & 5.8 & 4.2 & 3.7 & 5.0 & 0.9 \\
\hline The neighbours & & & & & & & & \\
part from the & & & & & & & & \\
total turnover & 66.8 & 63.3 & 53.0 & 43.5 & 37.2 & 30.8 & 14.6 & 8.5 \\
\hline
\end{tabular}

International

Economic

Co-operation

Figure 2.

The Seven AustroHungarian Successor States in the 1920 s
Table 2.

The Percentage

Turnover of Hungarian Foreign Trade with Neighbouring Countries 
International

Business

Review

2,3 hindered the restoration of the customs union that had eventually disintegrated in 1918. Some regional trading possibilities were offered by the so-called local border trade and by keeping up of selection exchange, but organising and handling of these transactions were made not directly through partners involved in the business, but through the capitals' ministries and foreign trade companies.

\section{Carpathian Region}

The peaceful revolutions of the recent past brought about the recognition that, with the introduction of a market economy, it is possible to revive regional trade co-operation in the region which had flourished in the past, beginning with those centres having the longest economic history.

Within a circle with a radius of $250 \mathrm{~km}$ around Sárospatak - one out of the several towns that has a long history - other towns can be found in the circle with a long economic history, from the Ukraine: Munkachevo, Ungvar, Lvov (Lemberg); to Poland: Rzeszow, Cracow; from Slovakia: Kosice, Banska Bystrica; to Rumania: Arad, Oradea, Cluj, Satu-Mare (Fig. 3). This offers opportunities of potential co-operation in infrastructure and markets, with political and economic stabilisation and the easing of border crossings and economy, which means that the products and consumers of our region will be able to reach this market, not indirectly, but directly (Dankó, 1991).

In accordance with this line of thought the geographical definition of the region by the Regional Research Centre of the Hungarian Academy of
Figure 3.

A Central European Regional with longterm Political and Economic Continuity

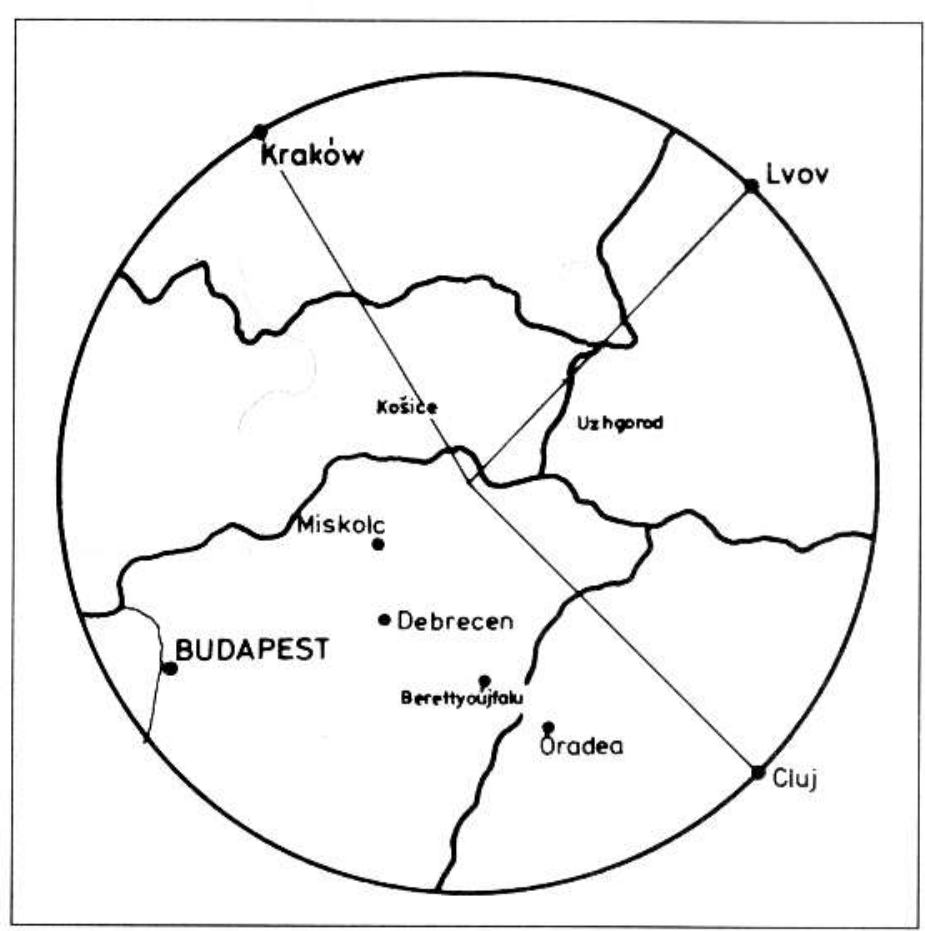


Sciences can be mentioned. This Centre proposes that the borders of the Carpathian region should coincide with the eastern borders of the former Austro-Hungarian Monarchy, because even the events of the last 70 years were insufficient to make the former economic and cultural unity totally disappear (Fig. 4).

Another point that supports this argument is that in the eastern parts of the Monarchy the Byzantine ritual was spread which symbolises a bridge between East and West because of the observance of Greek Orthodox as well as Roman Catholic religions. The Carpathian region comprises nearly 200,000 $\mathrm{km}^{2}$ and contains a population of about 20 million people, which means a sizeable market - especially when it is also taken into account that the region gives easy access to other parts of its constituent countries, thus encouraging direct international investment.

The region is formed by the following geographical-administrative units: in South-Poland: Cracow, Nowy Sacz, Tarnow, Rzeszow, Krosno, Przemysl voivodeships; in Czechoslovakia: the Middle- and East-Slovakia area; in Hungary: Borsod-Abaúj-Zemplén, Szabolcs-Szatmár-Bereg, Hajdú-Bihar counties; in Rumania: Bihar, Satu Mare, Salaj, Cluj, Maramures, BistritaNasaud, Suceava counties; in Ukraine: Lvov, Zakarpatye, Ivano-Frankovsk, Ternopol, Csenovci areas.

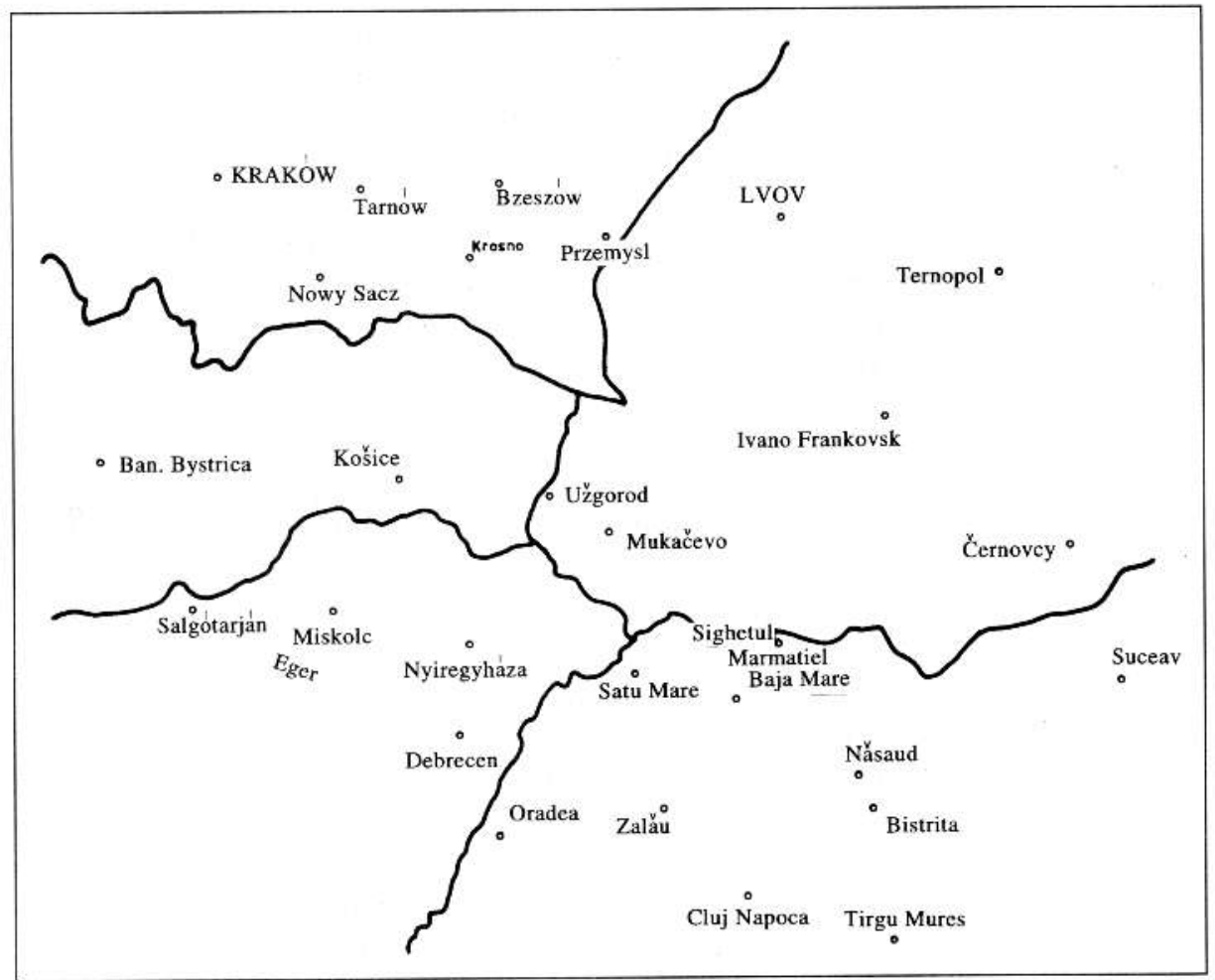

International Economic Co-operation
Figure 4. Administrative Units in the Proposed Carpathian Region 
International

Business

Review

2,3
The prime ministers and heads of state of Czech and Slovakian Republic, Hungary and Poland (which has areas in the Carpathian region and which is a leader in developing market economy) met in 1991 in Visegrad. One of the targets of the meeting was to outline free trade co-operation between the three countries. They rejected the idea of forming an integration or a block but signed a Co-operation Statement which contained the following: "they develop their economic co-operation, based on the market, and the mutually advantageous trade of products and services to promote the free movement of capital and workforce, and furthermore they are attempting to make favourable conditions for direct co-operation between companies, and for the international capital investment to increase the efficiency of the economy".

There is no question that there is a gap between the targets of the declared political ambitions and the possibilities for real action. The COMECON distorted relationships and product structure to the extent that, for example, out of Hungary's international trade turnover in 1989 Czechoslovakia's and Poland's joint share was only $7.67 \%$ and Austria's share was $11 \%$ (in 1990 these same figures were 5.75 and $13.6 \%$ ). According to the new trade rules effective from 1991, free customs inside the former COMECON countries have been succeeded by the application of the largest customs rates, which act as a price-raising factor in the import price. Furthermore in settlement of accounts convertible foreign exchange was introduced. For reduction in public transport services and for saving foreign currency an additional $10 \%$ of customs is imposed on the import of food and consumption goods in Czechoslovakia. Market-based trade with the former USSR and, from the beginning of December 1991, with Ukraine is hindered due to the partners' insolvency and administrative regulations. Development of foreign relationships with Rumania is mainly hindered by obtaining and storing difficulties of the product set-off. Polish-Hungarian economic co-operation is characterised by paralysis, both moving in the same direction, not towards each other towards the European Economic Community.

Beside the real difficulties of economic co-operation an equally important problem is the formerly suppressed nationalism, which in this region is growing from the level of people's nationalism to the level of state nationalism. Because of the lack of middle-classes in this region's changing societies this dangerous situation could be solved by the pacification and development of entrepreneurial thinking of workers of large factories, and by the development of the middle-classes (interview between Molnár and Lengyel, 1991).

\section{Carpathian-Tisza Regional Partnership}

The previously mentioned economic and social difficulties conceal certain contradictions in future possibilities of regional co-operation. In June of 1991 the author's proposal seemed somewhat Utopian, but it is now becoming more and more realistic that there could be developed co-operation in the Carpathian region similar to the Alps-Adriatic partnership (Dankó, 1991b). This argument is supported by the following paragraphs. 
At the Visegrad Meeting the "Visegrad Three", as they were known, proposed regional co-operation which deserves attention. The three countries concerned declared in Prague in the spring of 1992 that in the summer of the same year they would form a Central-European Free Trade Area (CEFTA). But as in the partnership agreement with the European Community, the contacts on the macro-level mean only a framework for the contacts between companies and institutions.

From the second half of the 19th century complementary economies were formed in the Austro-Hungarian Monarchy. Finding each other and organising themselves again after 70 years may start at a micro-level in these economies.

Another line of building co-operation in the region is the development of economic relationships between North-Hungary and East-Slovakia. What was formerly unthinkable in this region is becoming reality: on the Slavak side of the Hungarian border a branch-line to the gas line coming from Ukraine has been directed into Hungary, saving the necessity of a separate line. Similarly it is a good sign of co-operation that several new border-crossing stations are to be established in the region.

The Carpathian-Tisza Regional Partnership was formed in March 1992 from the former foundational organisation. Unfortunately, the declaration was only signed by the administrative authorities of Poland, Hungary and Ukraine, but the mutual co-operation is open to all the areas of the region and effort is being made to extend the co-operation.

Evidence of co-operation can be seen in Table 3, which shows the number of joint ventures established by Hungarian companies in the region showing comparisons with the total number of foreign Hungarian joint ventures in 1991 and the first quarter of 1992.

The plan of the "Carpathian Euroregion" is also supported by the Sasakawa "Peace Fund". As was said by Hudak Vasil, in July 1992 the 11th conference of West-East Safety Research Laboratories (IEWSS) would be held in Basle to draw the attention of the Carpathian region's countries upon the Basle Subregional Partnership as a model worth following. As the French and the Germans were able to overcome their historical prejudice and establish a very good co-operation after the Second World War so can the people living in the Carpathian basin. The Peace Fund would like to contribute to the forming of open societies in the subregion, where the ethnical and religious differences are settled tolerantly. According to their opinion "the regional co-operation is

\begin{tabular}{|lrrrr|}
\hline & \multicolumn{2}{c}{1991} & \multicolumn{2}{c|}{1992} \\
Country/Year & PCE & $(\%)$ & PCE & $(\%)$ \\
\hline Rumania & 87 & 24 & 101 & 25 \\
Czechoslovakia & 64 & 17 & 52 & 13 \\
USSR (Ukraine) & 52 & 14 & 133 & 33 \\
Poland & 2 & 1 & 8 & 2 \\
\hline Total for the region & 205 & 56 & 294 & 73 \\
\hline
\end{tabular}

\section{International \\ Economic \\ Cooperation}

Table 3 .

The Distribution of Enterprises from Neighbouring Countries with Investment in Hungary 
International Business Review 2,3 practically the highest level of co-operation, in which the participants gain more than if they work alone or against each other".

Legislation in the countries concerned in the Carpathian region has made it possible for foreigners to set up joint ventures, even with foreign majority. In Czechoslovakia the Federal Ministry of Finance's authorisation is necessary to set up a joint venture. Written application has to be handed in to the court of competent jurisdiction for the registration of the firm at the Court of Registration, which must contain the partnership contract and the firm's fundamental rule attested by the notary. It is also necessary to have a minimum of 100,000-Crown starting capital and a minimum of 20,000Crown foreign ownership. The joint venture will be allowed two years' exemption from taxes and two years' tax allowance.

In Poland to start a limited company a minimum of 10 million-Zloty and in the case of a share company 250 million-Zloty is necessary as nominal capital. The venture's foundation documents must be registered by a notary and then comes the registration of the firm at the Court of Registration, at the Statistical Office and at the tax office. Additional permissions may also be required in connection with the planned activity of the firm.

In Rumania investment permission has to be obtained from the privatisation agency in Bucharest. This permission and the planned foundation documents and the planned partnership contract have to be attested by the notary and then have to be submitted to the competent committee, which hands out the licence to practice. Following this process a request must be submitted to the County Court of Registration to register the firm. Finally, confirmation of the registration together with all the documents must be handed in to the Directorate of Finance, which also hands out a licence of practice. On the foundation of a limited company a minimum of 100,000 -Ley of nominal capital must be in cash.

In Ukraine, Company Law is applicable to joint ventures that are founded by foreigners. The minimal nominal capital has to be 100,000 roubles for a share company and 50,000 roubles for a limited company. Besides the foundation documents a further condition is to present the Articles of Association at the local government and at the local offices of the Ministry of Finance. Joint ventures having a minimum of 100,000 URSD foreign participation, are exempted from taxation on their profit for five years, $50 \%$ of their export is tax-free, they can export without special permission, and they can import equipment and materials necessary for the production from their foreign currency allocation in the budget, without any restriction.

The three concerned countries in the region have established a free trade area (CEFTA) based on mutuality and graduality — similar to EFTA — from January 1993 in Middle-Eastern Europe. The objectives in this area are to demolish customs and customs-like trade barriers, to establish a market of 70million people and to move the economies of the concerned countries closer to the EEC-EFTA relationships.

It can be seen from the previous discussion that regional co-operation in the Carpathain region is becoming closer to realisation. The governments of 
the concerned countries are contributing to the achievement of these objectives by controlling the demolition of trade barriers by deepening the relationships with the neighbouring countries, and by handing over the licences for regional co-operation to regional agencies. The final realisation depends on the people, on the ventures, on the local governments and on the institutions living and working in this area.

\section{References}

Berend, T.I. and Ránki, Gy. (1987) Európa gazdasága a XIX században (Europe's Economy in the 19th Century), pp. 378, 379, 386. Gondolat, Budapest.

Dankó, L. (1991a) Orientáció váltás gazdasági kapcsolatainkban (The Changing Orientation in Our Economic Connections). Sárospatak, No. 6.

Dankó, L. (1991b) A regionális külgazdasági együttmüködés gazdaságtörténeti megközelítése és adaptációs lehetöségei, ME tanszéki tudományos ülései, Miskolc 1991.06.04 (Regional Cooperation from the Economical History's Point of View and the Possibilities of Adaptation), Scientific Conference of the Economic Faculty of the University of Miskolc. Miskolc, June 1991.

Good, D. (1974) Stagnation and Take-off in Asutria 1873, 1913. The Economic History Review, Vol. 27, No. 1.

Hanák, P. (1991) Repüljünk a sassal (Fly with the Eagles). HVG, 16 February.

Jászi, O. (1982) A Habsburg Monarchia felbomlása ("Disintegration of the Hapsburg Monarchy"), pp. 205, 269. Gondolat, Budapest.

Kindleberger, C.P. (1966) European Integration and the International Integration. Columbia Journal of World Business, Vol. 1, No. 1.

Magyar Statisztikai Évkönyv (Hungarian Statistical Almanac) (1944). Budapest.

Napi Világ Gazdaság (1991) Molnár Zsolt interjúja Lengyel Lászlóval (Zsolt Molnár’s interview with László Lengyel), 20 December.

Surányi, R. (1990) A Brit Birodalomtól a Nemzetközösségig (From the British Empire to Commonwealth). História, No. 4, 18 pp.

Vörös, K. (1991) A magyar burzsoázia 1867-1918 (The Hungarian Bourgeoisie 1867-1918) História, No. 1, 12 p.

\section{International \\ Economic \\ Co-operation}

